\title{
An Empirical Analysis of Population Growth on Economic Development: The Case Study of Bangladesh
}

\author{
Shahjahan Ali, Khandaker Jahangir Alam, Shafiul Islam, Morshed Hossain \\ Department of Economics, Begum Rokeya University, Rangpur, Bangladesh \\ Email address: \\ sabrur_eco@yahoo.com (S. Ali), nirob_eco_ru@yahoo.com (K. J. Alam), shafi_eco_brur@yahoo.com (S. Islam), \\ morshed122001@yahoo.com (M. Hossain)
}

\section{To cite this article:}

Shahjahan Ali, Khandaker Jahangir Alam, Shafiul Islam, Morshed Hossain. An Empirical Analysis of Population Growth on Economic Development: The Case Study of Bangladesh. International Journal of Economics, Finance and Management Sciences.

Vol. 3, No. 3, 2015, pp. 252-259. doi: 10.11648/j.ijefm.20150303.21

\begin{abstract}
The population growth has a vital impact on economic development. There are two instructs of thought regarding this issue. Some researchers maintain that population has a negative impact on economic development while others are convinced that the effects are positive. Bangladesh's population increased 430 percent over the year1950-2012. Multivariate analyses of 1981 to 2014 data from the Bangladesh Economic Survey and from the International Financial Statistics yearbooks found significant and negative relationship between population growth and measures of economic advancement. These results demonstrate that rapid population growth is a real problem in Bangladesh because it contributes to lower investment growth and diminishes the savings rate. Today foreign investment and export promotion have only a small impact on Bangladesh's economic growth. Owing to its rapid population growth, Bangladesh has among the world's highest dependency ratios. Policy makers can address these serious economic consequences of rapid population growth by investing in family planning services. Development of independent media and liberal education in educational institutions will in time also help by encouraging a smaller family size ideal.
\end{abstract}

Keywords: Population Growth, Economic Development, Environment, Poverty, Bangladesh

\section{Introduction}

According to Thomas Frejka (1973) the population of an area is the total number of all individuals alive in a meticulous point in time. Population of a country is the number of its people and at all account is taken of differences of quantity; it is of quality in close relation to numbers. Thus population can be regarded as a label for a human aggregate. Minoru Tachi and Youchi Okazaki (1965), a country's economic development may be affected by the population growth. Due to the declining population growth, many developed countries face a serious problem of "ageing society" and experience labor shortage which puts a strain on their pension systems. On the other hand, many developing nations experience a rapid population growth which also affects their economic performance. The consequence of the relationship between population growth and economic development has been recognized by the development economists. As Dawson and Tiffin $(1998,149)$ put it: "The relationship between population growth and economic development has long been thought to be fundamental to our understanding of less developed countries (LDCs). In those developing countries where the relationship between population growth and economic performance could be described as positive, the demographic trends stimulate economic development and promote a rise in living standards This is because the population growth encourages competition in business activities and, as the country's population grows, the size of its potential market spread out also. The spreading out of the market, in its turn, encourages entrepreneurs to set up new businesses. A famous population economist, Julian Simon, stressed the positive side of population growth and distinguished human beings as the vital and most essential element for economic development. As Simon $(1996,589)$ put it, "The ultimate resource is people - skilled, spirited, and hopeful people who will exert their wills and imaginations for their own benefit, and inevitably they will benefit not only themselves but the rest of us as well". By contrast, if the relationship between population growth and economic performance of a country can be described as negative, the increase of population is likely to 
become an impediment to the country's economic development. This is because the rapid expansion of population increases dependency burden (i.e., the number of people who are considered to be economically unproductive, such as children and elder people). The negative views on the population growth have been prevailing over the positive opinions since Thomas Malthus warned about the danger of "over-population" in his "Pessimism about the economic impacts of population" over two centuries ago".
Population problem lies at the heart of Bangladesh's social, economic and political problems. At the time of independence, Bangladesh (former United Pakistan) was the 13th most populous country in the world with a population of 32.5 million but in 1996 it was sixth with a population of 140 million. Today Bangladesh is the 7th most populous country in the world with a population of 162 million. In 2050 its rank would be 8 th far below the Russia whose rank in 2014 is 9 (Table 1).

Table 1. The World's 10 Largest Countries in Population(in millions).

\begin{tabular}{|c|c|c|c|c|c|c|}
\hline \multicolumn{3}{|l|}{2014} & \multicolumn{2}{|l|}{2025} & \multicolumn{2}{|l|}{2050} \\
\hline Rank & Country & $\begin{array}{l}\text { Population } \\
\text { (Millions) }\end{array}$ & Country & $\begin{array}{l}\text { Projected Population } \\
\text { (Millions) }\end{array}$ & Country & $\begin{array}{l}\text { Projected Population } \\
\text { (Millions) }\end{array}$ \\
\hline 1 & China & 1350 & India & 1396 & India & 1657 \\
\hline 2 & India & 1220 & China & 1395 & China & 1304 \\
\hline 3 & USA & 316 & USA & 351 & USA & 423 \\
\hline 4 & Indonesia & 251 & Indonesia & 279 & Nigeria & 402 \\
\hline 5 & Brazil & 201 & Nigeria & 234 & Indonesia & 313 \\
\hline 6 & Pakistan & 193 & Brazil & 232 & Pakistan & 291 \\
\hline 7 & Nigeria & 174 & Pakistan & 228 & Ethiopia & 278 \\
\hline 8 & Bangladesh & 163 & Bangladesh & 198 & Brazil & 261 \\
\hline 9 & Russia & 142 & Ethiopia & 140 & Bangladesh & 250 \\
\hline \multirow[t]{4}{*}{10} & Japan & 127 & Mexico & 130 & Philippines & 172 \\
\hline & Mexico(11) & 116 & Philippines(11) & 129 & Mexico(11) & 148 \\
\hline & Philippines(12) & 105 & Russia(12) & 128 & Russia(16) & 109 \\
\hline & Ethiopia(13) & 93 & $\operatorname{Japan}(13)$ & 123 & $\operatorname{Japan}(17)$ & 107 \\
\hline
\end{tabular}

Population Reference Bureau, World Population Data Sheet, New York, 2015.

Table 2. Demographic Indicators- Bangladesh and Asian Countries.

\begin{tabular}{|c|c|c|c|c|c|c|c|c|}
\hline Country & $\begin{array}{l}\text { Births per } \\
1000 \\
\text { population }\end{array}$ & $\begin{array}{l}\text { Deaths per } \\
1000 \\
\text { population }\end{array}$ & $\begin{array}{l}\text { Infant } \\
\text { Mortality } \\
\text { Rate } \\
\end{array}$ & $\begin{array}{l}\text { Life } \\
\text { Expectancy } \\
\text { at Birth }\end{array}$ & $\begin{array}{l}\text { Total } \\
\text { Fertility } \\
\text { Rate }\end{array}$ & $\begin{array}{l}\text { \% Population } \\
\text { Below } 15 \text { Years }\end{array}$ & $\begin{array}{l}\text { \% of Population } \\
\text { Living Below US } \\
\$ 2 \text { per Day }\end{array}$ & $\begin{array}{l}\text { Per Capita } \\
\text { GNI (Current } \\
\text { US\$ ) }\end{array}$ \\
\hline Bangladesh & 27 & 8 & 65 & 61 & 3.00 & 35 & 83 & 470 \\
\hline India & 25 & 8 & 60 & 62 & 3.00 & 36 & 81 & 797 \\
\hline Pakistan & 34 & 10 & 85 & 62 & 4.80 & 42 & 66 & 707 \\
\hline China & 12 & 6 & 27 & 72 & 1.60 & 22 & 47 & 2200 \\
\hline Indonesia & 22 & 16 & 46 & 68 & 2.60 & 30 & 52 & 1211 \\
\hline Philippines & 22 & 10 & 75 & 60 & 2.70 & 29 & - & 1200 \\
\hline S. Korea & 10 & 5 & 5 & 77 & 1.20 & 19 & $<2$ & 17550 \\
\hline Thailand & 14 & 7 & 20 & 71 & 1.70 & 23 & 33 & 2600 \\
\hline Japan & 9 & 8 & 2.80 & 82 & 1.30 & 14 & - & 31150 \\
\hline
\end{tabular}

Source: The World Development Index (WDI) and Population Reference Bureau, World Population Data Sheet, New York, 2015.

Through 2050, Ethiopia will become one of the fastest populous countries placed on the 7 th place of the ranking; the United States is projected to remain in third place behind India, and China among the world's most populous countries. Bangladesh holds 9th position as most populated country according to the U.S. Census Bureau. These findings were derived from the population estimates and projections for 228 countries and areas released through the Census Bureau's International Data Base. This release includes revisions for
19 countries and provides information on population size and growth, mortality, fertility and net migration. "The Census Bureau has been preparing individual country population estimates and projections for more than 50 years," said Loraine West, a demographer in the Census Bureau's Population Division. "Current estimates and projections are provided through 2050 and are routinely updated as new data become available." Although the United States will maintain its third place position, the ranking of the countries with the 
10 largest populations in the world (see table 1) is expected to change over the next few decades. The top 10 countries each currently have at least 125 million inhabitants. Russia and Japan are projected to soon fall out of this group because of persistent low fertility rates, which have already caused their populations to decline. Russia's decline is also due in part to relatively high mortality. The countries expected to advance in the rankings are those with high fertility.

United States and Indonesia will keep hold of their position. Bangladesh's population problem is burning given its impetus and structure. Table 2 provides a bird's eye view of the important demographic indicators comparing Bangladesh's population profile with the Asian countries. Bangladesh's position vis-à-vis Asian countries are not agreeable and adequate. Bangladesh has the second birth rate as well as total fertility rate among the Asian countries with India. This is alarming and requires direct and immense attention and action. Bangladesh's population has grown at an average rate of $1.47 \%$ per annum since 1973 until mid 1980 s but it was an average rate of $2.68 \%$ per annum during 1986-2000 and since 2001 it is declining at an average rate of almost $1.76 \%$ per annum. Bangladesh's population has increased 4.3 times, whereas the population of South Korea increased only 2.4 times and over the period 1961 the population growth in India was $1.98 \%$ and at the end of 2001 it was $1.64 \%$. The population growth at end of July 2014 for Bangladesh, India and South Korea are 1.6\% (EST), 1.26\% and $0.45 \%$ respectively. Over the period of 1973 to end of June, 2014 per capita income in Bangladesh increased by only 5.3 times from $\$ 224$ in 1973 to $\$ 1190$ (at constant 2005 US\$), whereas in India it increased by 6.9 times from $\$ 226$ in 1973 to $\$ 1570$ in 2014 . No possible development plan can sustain such a rate of population growth. This evidence makes obvious the nature and severity of population problem. Since 1960s different governments have made serious efforts to check the unbridled population growth but the efforts have not succeeded. Because the common man has developed an irrational fear of practicing birth control mainly due to social reasons and cultural factors. In absolute numbers almost 128 million persons have been added during the last 41 years (1973-2014). The population density has increased three times from 391 persons per square kilometer in 1961 to 1203 persons per square kilometer in 2013. Rural-urban migration has swelled over the years due to push and pull factors and the urban population has increased from 5 million in 1961 to 56 million in 2014. The rate of urban population is 28.84 percent of total population and the urbanization rate is 3.56percent at the end of 2014. This situation has exerted an enormous pressure on the supply of infrastructure like housing, transportation, electricity, water, sewerage, health and educational faculties.

An addition sex ratio has declined over the years. It declined from 115 in 1972 to 111 in 1981 and to 107 in 1995 implying that the frequency of females has followed an increasing trend. This is distressing and painful and is expected to fall further that will strengthen social, psychological and economic problems for parents as well as females. There seems no elucidation to this agonizing problem in the short-run. Lee and Miller (1990), the traditional beliefs about the value of children, particularly sons, as an asset to be relied upon by their parents in agricultural production and to support them during old age have combined with the practice of polygamy, the fear of child mortality and low levels of female education to encourage high fertility. Moreover, the continuity of the matrilineal decent group and the influence of religions, which teach that children are gifts from God sharply, limits the prospects for lowering the birth rate. Afzal (2009), Polygamy will make the confusion not as good as confounded. It is extremely difficult to adopt the western social system and values. Improvement in operation and implementation of the family planning program, increase in female literacy rate and enhancement of women social status appear to be an agreeable solution. The U.S. Bureau for Census (2014), rapid population growth in Bangladesh has been alarming. Bangladesh though ranked 7 th in size adds more than twice as many peoples to the absolute growth of world population than USA which ranks third. This situation has created intractable and complicated social, economic and political problems that have negative impact on the macroeconomic stability of the economy. Ethnic-strife and deteriorating law and order situation, heartbreaking problems of housing, expensive educational and health facilities, traffic density and congestion, frequent and fatal accidents have made the common man life miserable and unsustainable. These problems will heighten if the population drive continues. These factors have collectively contributed to escalating cost of living that breeds macroeconomic instability on one hand and on the other hand, rising absolute and relative poverty and worsening income inequalities are the direct as well as indirect result of the aforesaid factors. Thus rapid population growth is the bone of disputation as well as root of the problems.

Minoru Tachi and Youchi Okazaki (1965), Socio-economic conditions would be better off if population were to grow slowly that would have also resulted in a better social and economic condition. Basak, J.K. (2009), Agricultural production in Bangladesh is highly influenced by different seasonal climatic variables such as high fluctuations of day and night temperatures, changing rainfall patterns, high carbon dioxide concentrations, humidity and day-length. It is also adversely affected by different climatic disasters such as floods, droughts, cyclones, storm surges, and sea level rise. For example, two rounds of floods and devastating cyclones Sidr in 2007 and cyclone Aila in 2009, severely damaged agricultural production, especially the rice production and resulted in a severe food crisis. According to the Food and Agricultural Organization (FAO, 2002), Agriculture is the mainstay of Bangladesh's economy. The arable land and almost all crops in Bangladesh rely on irrigation. Supplies of both arable land and fresh water are unlikely to increase, calling into question Bangladesh's ability to feed itself. Population pressures are threatening arable land, forests and water resources. The size of arable land holdings have decreased due to population growth, inadequate arable land reforms and inheritance patterns. Before the middle of this century, Bangladesh is projected to face a scarcity of arable 
land with even less arable land available per person than in China. Limited renewable resource supplies may be the biggest obstacle to increasing Bangladesh's food supply.

\section{Population Growth and Economic Development}

Afzal (2009), for many years development economists and social scientists have disputed the seriousness of the consequences of rapid population growth. Firstly, Population growth is not a problem but there are other issues. Underdevelopment, and not population growth is the genuine problem. As long as greater parts of the people in the developing countries remain poor, uneducated and physically weak, large family will constitute the only real source of social security. Population control programs are not expected to succeed when there is no incentive for the poor families to limit the family size. Population can only be an economic problem relative to the supply of natural and material resources. Developed countries with less than one-quarter of the world population consume $80 \%$ of the world resources. The higher fertility of the developing countries is the result of "over-consumption" of the world scarce resources by the rich countries. The average North American or European consumer consumes almost 16 times as much of the world food, energy and material resources as his or her counterpart in the developing countries. Thus the addition of another child in the developed countries consumes as much as the 16 children consume in the developing countries. The developed countries instead of asking the developing countries to check their population growth should reduce their needless consumption standards. Moreover, population distribution is causing the population problem. Some regions are underpopulated (e.g. Sylhet in Bangladesh, Balochistan province in Pakistan, few regions in Brazil and parts of sub-Saharan Africa) while other are over-populated (metropolitan cities in Dhaka, Chitagong, Bangladesh, and in other cities of others developing countries) due to concentration of employment opportunities and rural-urban migration, resulting from lopsided land and other productive resources distribution. Therefore, instead of checking population growth, government should discourage rural-urban migration so that more natural spatial distribution of population gains ground. Another important factor liable for population growth is the natural outcome of the women's lack of economic opportunity. Women often bear the inconsistent burdens of poverty, poor education, lack of jobs and limited social mobility. Their inferior status and roles are manifested in their high fertility. If women's roles and status, their education and economic well-being are improved, this will lead to smaller families and lower population growth. Secondly, Population growth reduction is a scheme of the capitalists' countries to keep developing countries in their reliance. This argument is closely related to the neocolonial dependence model which is a tortuous outgrowth of Marxist thinking. It has been argued that over anxiety of the developed countries about the population growth of the poor countries is an effort to arrest the development of the developing countries in order to maintain international status quo that serves their self-interest. The developed countries also passed through a period of considerable population growth that accelerated their own development. But the developed courtiers are pressurizing the poor countries to adopt aggressive population control programs to restrict their population growth that supports the second line of the propopulation growth argument. Finally, many developing countries population growth is desirable. This argument is a conventional argument. According to this argument, though rapid population growth results in additional demand for food, clothing, shelter, social services like education and health, and growing employment opportunities, the high population growth also adds to the labor supply that can be used for productive purposes and makes available potential for large markets for goods and services and therefore large population affords a big opportunity to benefit from demographic dividend which can add to growth. Neoclassical economists argue that free markets will always adjust to the problems created by population growth. It has also been argued that many rural areas in the developing countries are under populated due to scarcity of labor despite the availability of arable land and large increases in agriculture output will occur if labor were available to cultivate it. Many regions in Africa, Latin America and some parts of Asia have this situation. Furthermore, there are many ethnic, racial and religious groups in developing countries that are enamored of large families, and high population growth is considered desirable for political and military power. The last argument does not carry a significant weight because the peculiar situation obtaining in few regions does not demand high population growth.

The arguments which stated by Afzal (2009) carry some weight but this need to be weighed against the counter arguments of those who believe that rapid population growth is a real problem for LDCs (less developed countries). Coale A. et al (1958), one view is that all of the world's economic and social problems result from excessive population growth. The advocates maintain that population control or even decline is the most urgent task of the LDCs even if it requires severe and coercive measures like compulsory sterilization in South Asian Countries. Economists argue based on population-poverty cycle theory that rapid population growth gives way to negative economic consequences and this should be a real concern for the developing countries because population growth retards prospects of a better life for the already born by reducing savings rate at the household and national levels. Empirical evidence divides the negative consequences of population growth into seven categories. Rapid population growth lowers per capita income growth in most LDCs. The poor bears the brunt of the negative effects of population growth. They become landless, face loss in jobs, and the government reduction of expenditure on education and health. It is generally agreed that large family size and low incomes limit the opportunities of parents to 
educate all their children. High fertility harms the health of mothers and children. Rapid population growth generates food security problem and contributes to environmental degradation in the form of deforestation, soil erosion, unsafe water, air pollution and urban congestion. Rapid population growth is the major factor causing increasing international migration both legal and illegal.

The Malthusian population trap is the well-known theory of the relationship between population growth and economic development. According to this theory, human population grows geometrically while means of subsistence grow arithmetically being subject to the law of diminishing returns. This theory has convinced many development economists, demographers and policy makers that rapid population growth retards economic development by tightening job markets, generating underemployment and discouraging labor force mobility across sectors. Malthus Theory is based on a number of simplistic assumptions and hypotheses that do not stand the test of empirical verification.

In recent years, economists, Birdsall N (1988); Dasgupta $\mathrm{P}(1995)$; and Dreze J et al(1995) have attempted to apply the theory of consumer behavior to explain family size decisions in which children have been treated as consumption (and in LDCs investment) good, so that family's demand for children relative to other goods becomes a rational economic response. The economic theory of fertility has gained strong support in diverse developing countries have put forward a theory emphasizing family economics and capital formation. According to this theory rapid population growth forces families to consume what otherwise would be savings, adversely affecting national savings rates and thus capital formation and investment rates as well. Though the crosscountries evidence for a negative relationship between population growth and per capita economic growth is inconsistent, some studies find the expected relationship; others find no relationship. Studies done in the context of Bangladesh's experience have not examined the impact of population growth on the economic development of Bangladesh. The problem of population growth is not simply a problem of numbers but has welfare implications. If development means improvement in living standard, then how does the present population situation in Bangladesh affect the goals of development not only for present generations but also for future generations?

Since cross-countries studies differ on the relationship between population growth and development, given the present population situation in Bangladesh, we examine empirically the relationship between population growth and economic development in Bangladesh.

\section{Methodology}

Crenshaw et al (1997) used economic growth rates of 75 developing countries and regressed annual average percentage change in real GDP on demographic and macroeconomic variables for the period 1965 to 1990.They find out that an increase in the child population hinders economic progress, while an increase in adult population fosters economic development. Thus their major conclusion is that the "influence of population growth on economic growth depends on the age of the population segment that is growing". Their study suffers from many methodological problems besides their principal conclusion is debatable. They used two models that differ only in their specification of population growth as mentioned by the authors. Their study has some problems. Firstly, it is a cross-section study covering 75 countries. The cross section studies assume that parameters are similar across countries. This is an unrealistic assumption and therefore, these studies have not succeeded in providing a uniform support on population and economic growth relationship. The conclusions of these studies are doubtful and policy implications are hardly reliable. Secondly, it is dangerous and inadequate to generalize too much about developing countries, despite sharing common goals and problems because of different geography, resource endowment, historical and colonial background, cultural, social and political systems. To aggregate the experience of all developing countries is to attribute common elements that may not have any real existence. Thirdly, using population growth and labor force growth in the same equation turn out to be highly collinear. Their model suffers from multicollinearity casting doubts on the results. Finally, using private direct investment (1965-1978 average) is hardly tenable for all developing countries as it is 1980s phenomenon particularly in the context of Bangladesh's experience. "Since late 1980s foreign investment both direct and portfolio, has assumed immense importance as a source of foreign capital to developing countries. Therefore, their choice of variables, methodology and conclusions suffer from serious limitations due to aforementioned reasons. Because of the availability of time series data country specific studies are better and useful as they throw light on the distinguishing features of a country.

We, therefore, use the following simple model expressing the relationship between real GDP growth a proxy for economic growth and important macroeconomic variables having bearing on the economic growth. We presume that the economic growth is greatly influenced by the population growth; growth of exports, domestic and foreign investment, and market size represented by private consumption expenditure as percentage of GDP.

In equation form we have

$$
\begin{aligned}
& Y_{g}=\beta_{0}+\beta_{1} P O P_{g}+\beta_{2} I n v_{g}+\beta_{3} F I_{g}+\beta_{4} E X_{g}+\beta_{5} G E_{g}+\mu .(1) \\
& Y_{g}=\text { real GDP growth } \\
& P O P_{g}=\text { population growth } \\
& I n v_{g}=\text { real gross domestic investment growth } \\
& F I_{g}=\text { real foreign investment growth } \\
& E X_{g}=\text { exports growth } \\
& C_{a}=\text { private consumption as percentage of GDP } \\
& \mu=\text { white noise error term }
\end{aligned}
$$


The expected sign of all coefficients is positive except population growth. Except real gross domestic investment, data on other variables were obtained from World Development Index (WDI) while data on real gross domestic investment $\mathrm{t}$ were collected from IMF. The period of the study is from 1981 to 2012 .

\subsection{Durbin-Watson d Test}

The most illustrious test for detecting serial correlation is that developed by statisticians Durbin and Watson. It is popularly known as the Durbin-Watson d statistic, which is defined as

$$
d=\frac{\sum_{t=2}^{t=n}\left(\hat{\mu}_{t}-\mu_{t-1}\right)^{2}}{\sum_{t=2}^{t=n} \hat{\mu}_{t}^{2}}
$$

This is simply the ratio of the sum of squared differences in successive residuals to the RSS. Note that in the numerator of the $d$ statistic the number of observations is $n-1$ because one observation is lost in taking successive differences (Gujrati, 2004). This test is tattered to find problem of autocorrelation in the model.

\subsection{Jarque-Bera (JB) Tests of Normality}

The JB test of normality is an asymptotic, or large-sample, test. It is also based on the OLS residuals. This test first computes the skewness and kurtosis measures of the OLS residuals and uses the following test statistic

$$
J B=n\left[\frac{S^{2}}{6}+\frac{(K-3)^{2}}{24}\right]
$$

Where $\mathrm{n}=$ sample size, $\mathrm{S}=$ skewness coefficient, and $\mathrm{K}=$ kurtosis coefficient. For a normally distributed variable, $\mathrm{S}=$ 0 and $\mathrm{K}=3$. Therefore, the JB test of normality is a test of the joint hypothesis that $\mathrm{S}$ and $\mathrm{K}$ are 0 and 3, respectively. In that case the value of the JB statistic is projected to be 0 (Gujrati, 2004).

\section{Empiorical Results}

The estimation results of equation 1 have been shown in Table 3. The coefficients have expected and correct signs. This equation was subjected to specification and diagnostic tests Breusch-Godfrey LM (SC), White Heteroscedasticity (HS) and the Jarque-Bera (JB) test.

The Jarque-Bera (JB) statistic did not reject the hypothesis that the residuals originate from a normal distribution. For residual autocorrelation Breusch-Godfrey LM (SC) test does not reject the hypothesis of no autocorrelation. R2 and DW are satisfactory.

Table 3. Ordinary Least Square.

\begin{tabular}{lllll}
\hline $\begin{array}{l}\text { Dependent Variable: YG } \\
\text { Method: Least Squares } \\
\text { Sample: } 1981 \text { 2014 } \\
\text { Included observations: } \mathbf{3 4}\end{array}$ & & & & \\
\hline Variable & Coefficient & Std. Error & t-Statistic & Prob. \\
\hline$\beta_{0}$ & 6.439534 & 4.877378 & 1.320286 & 0.1982 \\
$E X_{g}$ & 0.034763 & 0.155875 & 0.223018 & 0.8253 \\
$P O P_{g}$ & -1.233333 & 1.051302 & -1.173148 & 0.2514 \\
$I n v_{g}$ & 0.038983 & 0.191734 & 0.203316 & 0.8405 \\
$F I_{g}$ & 6.44 & 1.16 & 0.554035 & 0.5843 \\
$C_{a}$ & .24 & $2.00 \mathrm{E}-11$ & -0.521583 & 0.6064 \\
R-squared & 0.65 & $\mathrm{JB}$ & $\mathrm{F}=1.99(0.36)$ & \\
F-statistic & 9.688716 & & & \\
Prob(F-statistic) & 0.000026 & & & \\
Durbin-Watson stat & 2.429403 & & & \\
\hline
\end{tabular}

The coefficient for population growth is negative and significantly different from zero meaning that population growth adversely affects the economic growth. This does not support the view that population growth is not a real problem. For a country like Bangladesh, rapid population growth is indeed a real and important problem because Bangladesh has the highest second total fertility in the Asian countries (Table 2), besides the other negative consequences of rapid population growth mentioned above. High population growth has become an important limiting factor for achieving the overall development goals. It is highly desirable this rampant population growth is checked to release the pressure on the existing infrastructure if the gains of growth are not eaten up by the high population growth. Millions of Bangladeshi is working abroad notably in oil-rich Middle Eastern countries and the remittances are a significant source of foreign exchange earnings and form an important part of the current account balance. Resources that could be used for productive purposes are diverted to satisfy the consumption needs that 
have adversely affected the national saving rate. Bangladesh had to seek external financial assistance that has burdened the country with heavy debt whose service over years has become unpalatable. Bangladesh has one of the lowest savings rate in Asia. According to the Asian Development Outlook 2002, the domestic saving in Bangladesh in 2002 was $20.7 \%$ of GDP as compared to $23.6 \%$ in India, $23 \%$ in Indonesia and $38 \%$ in China. Investment growth is positive and highly significant implying that growth in investment will significantly contribute to economic growth, which in turn depends on high saving rate. High rates of domestic saving are important because savings provide most of the funds for investment. Empirical evidence for East Asia shows that there is a strong positive correlation between domestic saving and investment rates by Afzal (2009) in his work entitled estimating saving and investment functions in South Asia. Coefficients for foreign investment and exports are positive though not significant. Foreign investment and export promotion are more recent phenomenon in Bangladesh.

Export promotion policies were adopted and this policy has been moderately successful. Now foreign aid is not available at concessional terms. That is why various governments have offered diverse incentives to attract foreign investment. The Economic Review of Bangladesh stated "substantial benefits in the shape of capital, advance technology, new managerial and technical skills, marketing expertise, employmentgeneration and linkages with the outside world" are the potential advantages of foreign investment. Private consumption as percentage of GDP (Ca) is also positive. Consumption being a positive function of income contributes positively to economic growth, but being not significant implies that its impact is not noteworthy. Therefore, in the aggregate demand management policies, exclusive reliance on private consumption is less likely to generate desired results. Compared to the Asian countries (Table 2), Bangladesh has the third highest dependent population below 15 years. This large proportion of children hinders economic growth because they are non-productive members of the society and must be supported financially by the active labor force. This increases marginal propensity to consume. Saving rate is reduced that adversely affects the investment environment. Living standards fall and in the final analysis productive efficiency of the working force is badly affected.

\section{Population, Environment and Poverty}

Like most developing countries, Bangladesh faces serious environmental problems. Rapid population growth and impressive GDP growth have put immense pressure on the country's natural resource base and have significantly increased levels of pollution. Rapid expansion in industrial production and urbanization has led to increased levels of industrial waste, water pollution, solid waste, and vehicle emissions that have resulted in serious health problems in many areas of the country. There is a close association between rapid population growth and poverty. With stagnant or deteriorating employment opportunities, a persistent increase in population would result in increasing relative and absolute poverty. More recent evidence on the incidence of poverty indicates that poverty that declined in $1970 \mathrm{~s}$ and $1980 \mathrm{~s}$ increased in 1990s that have adversely affected the poor families demand for education and the health and housing conditions have also deteriorated. The issue of poverty in Bangladesh has its significance for sustainable development. Long- run development is not possible without protecting the rights of the vulnerable groups and the participation of the entire population in the development process.

The incidence of poverty increased in 1990s mainly because of dismal economic growth. Growth has always helped in poverty reduction. The dominant effect of growth has been of poverty reduction. Poverty can be taken care of if the economy succeeds in achieving a respectable economic growth of more than $6 \%$. Diverse policy options could be used to take care of poverty incidence. Policies are adopted that reduce the concentrated control of assets and unequal access to education and income- earning opportunities. Since rapid economic growth and population growth are incompatible, population growth must be reduced.

\section{Conclusion and Recommendation}

Since the publication of Thomas Malthus Essay on the Principle of Population in 1798 development economists and policy makers have devoted a good deal of effort to address the problem of population growth. There is divergence of opinion regarding the desirability of population growth. Some view rapid population growth a real problem while others assert that it is not a matter of grave concern. Cross countries evidence on the population growth and economic growth relationship is not consistent and uniform. These studies are based on the unrealistic assumption that parameters are similar across countries and aggregating the experience of all developing countries is to attribute common elements that may not have any real existence. Availability of time series data has made the country-specific studies desirable and useful as they throw light on the distinguishing features of a country. Rapid population growth has assumed alarming proportions in Bangladesh. It was the 13th most populous country with a population of 72.5 million in 1973; today Bangladesh is the 7 th most populous country in the world with a population of 162 million. Bangladesh's population problem is distressing given its momentum and structure. Bangladesh has the second highest birth as well as total fertility rate among the Asian countries. During the four decades 1971-2011, Bangladesh's population has increased 430 percent. Government policies and programs to contain the uninhibited population growth have not made an enviable success. The common man does not realize the negative economic consequences of rapid population growth due to social reasons and cultural factors. We estimated a simple model to examine empirically the relationship between population growth and economic development in Bangladesh. Specification and diagnostic tests supported the statistical appropriateness of the model. Highly significant and negative 
coefficient of population growth demonstrates that population growth is a real problem in Bangladesh because it adversely affects the economic growth. Resources instead of being directed to productive channels are consumed by the exploding population. Positive and highly significant investment coefficient implies that investment growth will considerably contribute to economic growth which in turn depends on high saving rate. Foreign investment and export promotion are expected to have benign impact on economic growth of Bangladesh.

However, foreign investment has to be carried out cautiously and vigilantly. Without investigating in depth the positive and negative aspects of foreign investment, it is most likely that the uncritical acceptance of foreign investment may turn disagreeable like foreign aid. Bangladesh has the highest dependent population that hinders economic growth because this population encompasses non-productive members of the society. Poverty can be taken care of if the economy succeeds in achieving a respectable economic growth of more than $6 \%$.Plans to reduce population growth over the years do not seem to have succeeded. Therefore, population growth has become a critical issue that discourages economic development and must be addressed seriously and squarely In order that the country has respectable economic growth. Provision of scientific and liberal education in educational institutions and self-governing media can make the people think independently and rationally that will help encourage a smaller family size ideal.

This study opens up new grounds for further research. Further research can address the issue on why the population can play negative role on economic development. It may also study that why we do not make our population as manpower. Further research might concentrate on the reason behind population over population and since it is exist within the country, find out the way to make the population as man power in the country which play an important role on economic development in Bangladesh.

\section{References}

[1] Afzal M. Causality between exports, world income and economic growth in Pakistan. Int Eco J 2006; 20: 63-77.

[2] Afzal M. Estimating saving and investment functions in Pakistan. Philip Rev Eco 2004; 41: 67-78.

[3] Ali SS, Tahir S. Dynamics of growth, poverty and inequality in Pakistan. Pak Dev Rev 1999; 38: 837-58.

[4] Bangladesh Economic Review, Ministry of Finance, Government Republic of Bangladesh-2014.

[5] Basak, J.K. 2009. Effects of Increasing Temperature and Population Growth on Rice Production in Bangladesh: Implications for Food Security. Published by Unnayan Onneshan-The Innovators Dhaka, Bangladesh.

[6] Bhatti, Ali M, Haque R, Javed T, A sectoral analysis of poverty in Pakistan. Pak Dev Rev 1999; 38: 859-72.
[7] Birdsall N, Economic approaches to population growth. In Hollis B, Chenery T.N., Srinwasan, Eds. Handbook of Development Economics, vol.1, Amsterdam: North Holland; 1988.

[8] Brandon C. Valuing environmental costs in Pakistan. The economy-wide impact of environmental degradation 1995, Background paper for Pakistan 2010 Report. Washington D.C., World Bank, Asia Technical Department 1995.

[9] Coale, Ansely J. Population trends and economic development, in world population and US policy: the choices ahead. J Menken Ed, New York: W.W. Norton; 1986.

[10] Coale A, Edgar J, Hoover M. Population growth and economic development in low income countries. Princeton, New Jersey: Princeton University Press; 1958.

[11] Crenshaw, Edward M, Ansari ZA, Christenson M. Population dynamics and economic development: age-specific population growth rates and economic growth in developing countries: 1965 to 1990. Am Soc Rev 1997; 62: 974-84.

[12] Gujrati, D. N, (2004),” Basic Econometrics” McGraw Hill Education, 4th Ed. Pp 300-560

[13] Dasgupta P. The Population problem: theory and evidence, J Eco Liter 1995; 33: 1879-1902.

[14] Dreze J, Murthi M, Guio AC. Mortality, fertility, and gender bias in India: a district level Analysis. Popul Dev Rev 1995; 21: 745-82.

[15] IMF, International Financial Statistics (various issues), Washington D.C.

[16] Mahmood N, Ali SM, Population planning in Pakistan: issues in implementation and its impact. Pak Dev Rev 1997; 36: 87588 .

[17] Population Reference Bureau, World Population Data Sheet, New York, 2015.

[18] Rosen JE, Conly SR. Pakistan's population program: the challenges ahead 1995 .

[19] Sadik N, Social Change the Essence of development, Pak Dev Rev 1997; 36: $315-2 \overline{0}$.

[20] Shahjahan Ali, Md. Rukunujjaman, Khandaker JahangirAlam. An Empirical Analysis of Foreign Direct Investment and Economic Growth in Bangladesh. International Journal of Business and Economics Research. Vol. 4, No. 1, 2015, pp. 110. doi: $10.11648 /$ j.ijber.20150401.11

[21] TACHI, M. and OKAZAKI, Y. (1969), JAPAN'S POSTWAR POPULATION AND LABOR FORCE. The Developing Economies, 7: 170-179. doi:10.1111/j.17461049.1969.tb00528.x

[22] Thomas Frejka. The Future of population growth: Alternative Paths to Equilibrium A. Wiley Interscience Publication, New York U.S, 1972.

[23] Todaro MP, Stephen CS. Economic Development. 8th ed. Singapore; Pearson Education, 2004.

[24] World development report. World Bank. Washington D.C.: Oxford University Press; 2014. 